\title{
OCENA TRENDÓW ROZWOJU OBSZARÓW WIEJSKICH POMORZA W PIERWSZEJ DEKADZIE PO AKCESJI DO UNII EUROPEJSKIEJ
}

\section{EVALUATION OF TRENDS FOR THE DEVELOPMENT OF POMERANIA'S RURAL AREAS IN THE FIRST DECADE AFTER THE ACCESSION TO THE EUROPEAN UNION}

\author{
Gabriela CZAPIEWSKA \\ Akademia Pomorska w Słupsku \\ Instytut Geografii i Studiów Regionalnych \\ ul. Partyzantów 27, 76-200 Słupsk \\ gabrielaczapiewska@poczta.onet.pl
}

Zarys treści: W niniejszym artykule, na przykładzie Pomorza (województwa pomorskiego i zachodniopomorskiego), zobrazowano dokonujące się zmiany na obszarach wiejskich w pierwszej dekadzie po akcesji do Unii Europejskiej. Wykazano wpływ środków unijnych na współczesne procesy przeobrażeń społeczno-gospodarczych badanych wsi. Ocenie poddano wybrane elementy potencjału rozwojowego obszarów wiejskich Pomorza. Praca podzielona została na dwie części. W pierwszej przedstawiono zróżnicowanie układów funkcjonalnych w oparciu o metodologię delimitacji gmin z uwzględnieniem roli procesów demograficznych i gospodarczych w rozwoju pomorskich wsi, a także uwarunkowań środowiska przyrodniczego. Ważnym czynnikiem rozwoju prezentowanego regionu jest unikatowe środowisko i walory turystyczne, głównie bliskość Bałtyku oraz występowanie lasów i jezior, umożliwiających rozwój różnych form turystyki i wypoczynku. Pomorze charakteryzuje również różnorodność kulturowa, wynikająca z tożsamości regionalnej i lokalnej. Pomorskie wsie charakteryzują się dużym zróżnicowaniem układów funkcjonalnych, a ich stan ma istotne znaczenie dla warunków życia mieszkańców i możliwości gospodarowania, a także kierunków i tempa rozwoju regionu. Z kolei w drugiej części pracy pokazano zmiany w rolnictwie badanego regionu po wejściu Polski do Unii Europejskiej. W sposób szczególny uwzględniono rozwój tych terenów, na których rolnictwo pełni nadal dominującą funkcję gospodarczą.

Słowa kluczowe: obszary wiejskie, rozwój społeczno-gospodarczy, fundusze Unii Europejskiej, Pomorze.

\section{Wstęp}

Zmiany w sferze społecznej i ekonomicznej zapoczątkowane w okresie transformacji uległy znacznemu przyspieszeniu po wejściu Polski do Unii Europejskiej. Istotne znaczenie dla rozwoju obszarów wiejskich - w wymiarze pozytywnym - miała restrukturyzacja i modernizacja rolnictwa, rozbudowa systemów infrastruktury technicznej oraz społecznej, intensywny rozwój pozarolniczej działalności gospodarczej, wzrost aktywności i integracji społeczności lokalnej. 
Celem artykułu jest zobrazowanie zmian dokonujących się na obszarach wiejskich Pomorza (województwa pomorskiego i zachodniopomorskiego) w pierwszej dekadzie po akcesji do Unii Europejskiej. Wykazano wpływ środków unijnych na współczesne procesy przeobrażeń społeczno-gospodarczych badanych wsi. Poddano ocenie wybrane elementy potencjału rozwojowego obszarów wiejskich Pomorza. Kryterium ich doboru stanowiła analiza literatury z zakresu podjętej problematyki badawczej, autorstwa m.in. J. Bańskiego (2013, 2014), K. Heffnera (2013), A. Rosnera (2010, 2012) i R. Rudnickiego (2010).

Praca podzielona została na dwie części. W pierwszej przedstawiono zróżnicowanie układów funkcjonalnych w oparciu o metodologię delimitacji gmin z uwzględnieniem roli procesów demograficznych i gospodarczych w rozwoju pomorskich wsi, a także uwarunkowań środowiska przyrodniczego. Z kolei w drugiej części pokazano zmiany w rolnictwie badanego regionu po wejściu do Unii Europejskiej. W sposób szczególny uwzględniono rozwój tych terenów, na których rolnictwo pełni nadal dominującą funkcję gospodarczą.

Zakres przestrzenny badań obejmował województwa pomorskie i zachodniopomorskie, zajmujące łącznie powierzchnię 41202,82 km², co stanowi 13,1\% powierzchni kraju. Na obszary wiejskie przypada 93,8\% powierzchni Pomorza. W postępowaniu badawczym wykorzystano dane ze źródeł wtórnych - publikacje naukowe z zakresu podjętej problematyki badawczej oraz materiały statystyczne pochodzące w znacznej mierze z Banku Danych Lokalnych Głównego Urzędu Statystycznego (GUS). Zakres czasowy przeprowadzonej analizy objął lata 2003-2013. Pozwoliło to na pokazanie sytuacji obszarów wiejskich Pomorza przed akcesją do Unii Europejskiej oraz po okresie dziewięciu lat korzystania z funduszy europejskich, co w zasadniczy sposób wpłynęło na trendy rozwojowe badanego regionu.

\section{Wybrane elementy potencjału rozwojowego obszarów wiejskich i współczesne procesy ich przeobrażeń}

Zróżnicowanie potencjału rozwojowego i stopień wykorzystania walorów przestrzeni mają ogromny wpływ na charakter struktury demograficznej i przestrzenno-funkcjonalnej obszarów wiejskich (Kiniorska 2009). Pomorskie wsie charakteryzują się dużym zróżnicowaniem układów funkcjonalnych, a ich stan ma istotne znaczenie dla warunków życia mieszkańców i możliwości gospodarowania, a także kierunków i tempa rozwoju regionu. Nowe strategie obszarów wiejskich zostały ukierunkowane na ich wielofunkcyjność, rozumianą przede wszystkim w kontekście poprawy warunków życia i pracy rodzin mieszkających na wsi (Kamińska 2011). Współcześnie ważną rolę w rozwoju obszarów wiejskich Pomorza odgrywają procesy demograficzne oraz gospodarcze, które są długotrwałe i mają charakter ciągły.

Odnosząc się do metodologii delimitacji gmin autorstwa A. Rosnera (2010), warto podkreślić, iż na terenie Pomorza zdecydowanie przeważają obszary wiejskie niewyróżniające się znaczącym poziomem rozwoju ani jego dynamiką, czyli zasadniczo nieodbiegające od przeciętnej dla kraju (ryc. 1). Udział tego typu gmin stanowi na badanym obszarze $58,7 \%$ ogółu gmin wiejskich i miejsko-wiejskich. Widoczne jest to dość wyraźnie, zwłaszcza w województwie pomorskim. W grupie tej znalazły się także gminy o dobrze rozwiniętym rolnictwie. Mniej liczną grupę stanowią w badanym regionie gminy o cechach peryferyjnych, głównie niegdyś związane z rolnictwem uspołecznionym, w których do dziś widoczne są jeszcze społeczno-ekonomiczne konsekwencje bezrobocia. W większym stopniu skupiają się one w województwie zachodniopomorskim. Jednak na Pomorzu obszarów 
należących do wskazanej grupy jest stosunkowo niewiele (8\%), podczas gdy w skali kraju w grupie tej znalazło się aż 44,5\% gmin. Z kolei obszary wiejskie wybitnie rozwinięte oraz dynamicznie rozwijające się stanowią 1/3 wszystkich gmin (33,3\%). Zasadniczo koncentrują się one wokół dużych ośrodków miejskich, głównie Szczecina i Trójmiasta, a także Świnoujścia, Kołobrzegu i Koszalina (ryc. 1).

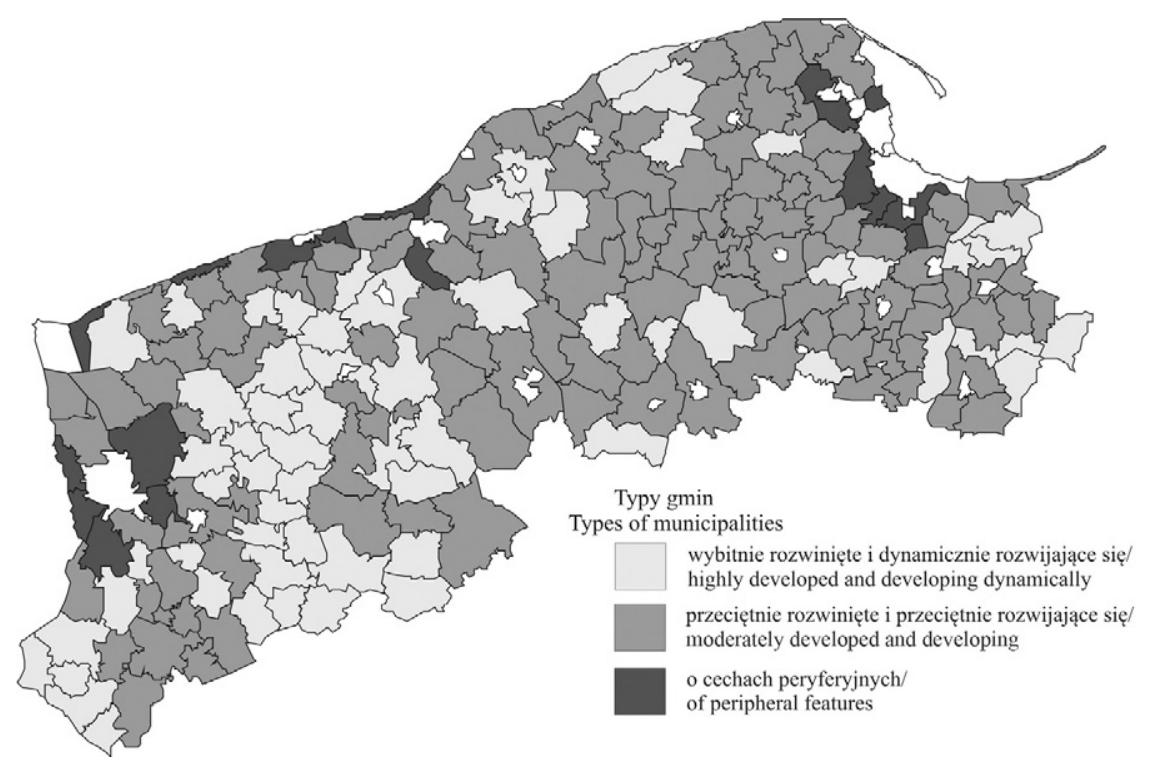

Ryc. 1. Obszary wiejskie Pomorza pod względem poziomu i dynamiki rozwoju Źródło: opracowanie własne na podstawie: Rosner 2010.

Rural areas of Pomerania in terms of the level and dynamics of development Source: own study based on: Rosner 2010

Ważną rolę w kształtowaniu współczesnego oblicza wsi mają zarówno uwarunkowania środowiska przyrodniczego, jak i czynniki związane z intensywnością zasiedlania, rozwojem demograficznym oraz procesy urbanizacyjne. Według danych GUS na koniec 2013 r. obszary wiejskie województwa pomorskiego i zachodniopomorskiego zamieszkiwało łącznie 1339539 osób, tj. 33,3\% ogółu ludności badanego regionu. Największa koncentracja ludności wiejskiej występuje na terenach atrakcyjnych turystycznie lub inwestycyjnie, a także tam, gdzie warunki do produkcji rolniczej są korzystne. Są to powiaty: kartuski (103 689 osób), wejherowski (85 043 osób), słupski (77 372 osób), gdański (976 389 osób), starogardzki (64 693 osób) czy koszaliński (52 054 osób). Zatem na Pomorzu istotny wpływ na rozmieszczenie ludności wywierają warunki środowiska geograficznego, ale także siła oddziaływania miejskich ośrodków regionalnych i lokalnych. Warto podkreślić, iż liczba mieszkańców pomorskich wsi wzrasta sukcesywnie, przy czym zdecydowanie wyraźniej proces ten uwidacznia się w przypadku województwa pomorskiego (tab. 1). W latach 2003-2013 na obszarach wiejskich Pomorza przybyło łącznie 113074 mieszkańców, co stanowi 9,2\% wzrost, podczas gdy w skali kraju był on zdecydowanie niższy i wyniósł jedynie 3,8\%.

Obszary wiejskie Pomorza stają się coraz bardziej atrakcyjne jako miejsce zamieszkania. Szczególnie szybko wzrasta liczba ludności we wsiach ulokowanych w promieniu kilkunastu kilometrów od większych miast, które w dużym stopniu mają zurbanizowany 
charakter. Od czasu wejścia do Unii Europejskiej, dzięki możliwościom korzystania ze środków finansowych w ramach różnorodnych programów, znaczącej poprawie na tych terenach uległa infrastruktura techniczna i społeczna, co spowodowało, że coraz chętniej osiedlają się tam zarówno osoby młode, jak i te w wieku poprodukcyjnym. Jednocześnie, uwzględniając prognozy GUS (opracowane na bazie NSP 2011), należy zwrócić uwagę, iż rozwój demograficzny badanego regionu nadal będzie wykazywał tendencję wzrostową i do 2030 r. udział ludności wiejskiej wzrośnie na Pomorzu średnio o 7,7\%, tj. o prawie 104,2 tys. osób, a w ciągu kolejnej dekady o 1,7\%.

Tabela 1. Zmiany liczby ludności na obszarach wiejskich Pomorza według faktycznego miejsca zamieszkania w latach 2003-2013

\begin{tabular}{|c|c|c|c|c|}
\hline Lata & $\begin{array}{c}\text { Województwo } \\
\text { pomorskie }\end{array}$ & $\begin{array}{c}\text { Województwo } \\
\text { zachodniopomorskie }\end{array}$ & Pomorze & Polska \\
\hline 2003 & 705679 & 520786 & 1226465 & 14677219 \\
2004 & 712680 & 520529 & 1233209 & 14703749 \\
2005 & 718910 & 522270 & 1241180 & 14733315 \\
2006 & 726342 & 524573 & 1250915 & 14756601 \\
2007 & 736046 & 526727 & 1262773 & 14798756 \\
2008 & 744408 & 528899 & 1273307 & 14847695 \\
2009 & 753513 & 530589 & 1284102 & 14889142 \\
2010 & 776284 & 537565 & 1313849 & 15113361 \\
2011 & 785065 & 536772 & 1321837 & 15152619 \\
2012 & 792591 & 537831 & 1330422 & 15197010 \\
2013 & 800368 & 539171 & 1339539 & 15237750 \\
\hline
\end{tabular}

Źródło: Opracowanie własne na podstawie danych GUS, Bank Danych Lokalnych; www.stat.gov.pl (dostęp z dnia 18.05.2015)

Istotnym czynnikiem rozwoju wsi województwa pomorskiego jest unikatowe środowisko i walory turystyczne, głównie bliskość Bałtyku oraz występowanie lasów i jezior, umożliwiających rozwój różnych form turystyki i wypoczynku. Pomorze charakteryzuje również różnorodność kulturowa, wynikająca z tożsamości regionalnej i lokalnej. Warto dodać, iż dziedzictwo kulturowe coraz częściej traktowane jest jako istotny czynnik rozwoju lokalnego (sposób na aktywizację gospodarczą, tworzenie nowych miejsc pracy oraz kreowanie pozytywnego wizerunku danego obszaru).

Przeobrażenia obszarów wiejskich badanego regionu zmierzają zatem w kierunku rozwoju wielofunkcyjnego i zrównoważonego. Wsie pełniące niegdyś funkcje rolnicze stają się wsiami techno-produkcyjnymi. Z danych GUS wynika, iż na koniec 2013 r. działalność gospodarczą na terenie województwa pomorskiego prowadziły łącznie 271784 podmioty gospodarcze, w tym 65516 (24,1\%) na obszarach wiejskich, zaś w województwie zachodniopomorskim - odpowiednio 219579 i 48588 (22,1\%). W latach 2003-2013 ich udział wzrósł na obszarach wiejskich pomorskiego aż o 45,8\%, a zachodniopomorskiego o 30,6\%. Z perspektywy rozwoju wsi wzrost liczby przedsiębiorstw wskazuje na aktywność ekonomiczną lokalnych społeczności. Zdecydowanie największa liczba podmiotów gospodar- 
czych funkcjonowała na obszarach wiejskich gmin: Pruszcz Gdański (3408), Żukowo (2956), Kolbudy (2064), Wejherowo (2033) i Puck (1952), zlokalizowanych na terenie województwa pomorskiego. W przypadku województwa zachodniopomorskiego było ich znacznie mniej. Najwyższe wartości odnotowano w gminach: Kołobrzeg (1800), Kołbaskowo (1713), Goleniów (1492) i Mielno (1429). Z powyższego wynika, że rozwój przedsiębiorczości jest najbardziej intensywny na obszarach wiejskich w pobliżu dużych miast oraz na terenach nadmorskich. Zazwyczaj są to małe i średnie przedsiębiorstwa, które ze względu na specyficzne cechy i dużą elastyczność działania mają większą możliwość tworzenia tanich miejsc pracy, a tym samym zdolności wchłaniania lokalnych nadwyżek siły roboczej. Należy dodać, iż gminy zlokalizowane w strefie podmiejskiej przyciągają inwestorów lepiej rozwiniętą infrastrukturą, a jednocześnie stanowią rynek zbytu dla lokalnych przedsiębiorców.

W latach 2003-2013 na badanym terenie nastąpił także znaczący wzrost podmiotów gospodarczych w przeliczeniu na 1000 osób, w przypadku województwa pomorskiego o $28,1 \%$, zaś zachodniopomorskiego o 26,8\% (ryc. 2). Na rozwój podmiotów gospodarczych na obszarach wiejskich Pomorza niewątpliwie znaczący wpływ miały dotacje unijne, chociażby na rozwój mikroprzedsiębiorstw w ramach ZPORR czy wcześniej w latach 2004-2006 SPO „Wzrost rozwoju konkurencyjności przedsiębiorstw”.

Aktywizacja środowisk wiejskich i restrukturyzacja wsi za pośrednictwem lokalnych przedsiębiorców jest nadrzędnym celem Unii Europejskiej. Zdaniem M. Kłodzińskiego (1996) rozwój gminy zależy głównie od działalności przedsiębiorców, którzy staną się liderami wiejskiej przedsiębiorczości. Dla rolników Pomorza najbardziej charakterystyczną działalnością pozarolniczą jest zakładanie gospodarstw agroturystycznych, których rokrocznie przybywa, a ich oferta jest systematycznie urozmaicana.

Uwarunkowania przyrodnicze miały i nadal mają podstawowe znaczenie w rozwoju obszarów wiejskich Pomorza. Znaczna ich część cechuje się dużym potencjałem do rozwoju agroturystyki, a zwłaszcza gminy nadmorskie (co związane jest z bliskością morza), Pojezierze Drawskie czy centralna część Pojezierza Kaszubskiego (liczne jeziora i lasy) oraz zachodnia część Borów Tucholskich (Park Narodowy Bory Tucholskie).

O dynamicznym rozwoju obszarów wiejskich Pomorza w ostatnich latach świadczą także rosnące dochody w przeliczeniu na 1 mieszkańca (ryc. 3). Przed akcesją Polski do Unii Europejskiej w 2003 r. średnie dochody oscylowały wokół kwoty 1500 zł (w pomorskim - 1525,61 zł, zachodniopomorskim - 1559,29 zł). Najwyższe wartości osiągano w gminach nadmorskich, jak: Rewal (6124 zł), Ustronie Morskie (4039 zł), Mielno (3702 zł), Dziwnów (3550zł).

W latach 2003-2013 średni dochód w przeliczeniu na 1 mieszkańca zwiększył się o około $120 \%$ i wynosił w województwie pomorskim 3346 zł, a zachodniopomorskim 3496 zł. Porównywalny wzrost odnotowano w skali kraju (z 1424 zł w 2003 r. do 3099 zł w 2013 r., tj o 117\%). Zdecydowanie najwyższy wskaźnik był w gminach o atrakcyjnym położeniu (ryc. 4). Na terenie województwa zachodniopomorskiego wiodącymi pod tym względem były gminy: Nowe Warpno (29 576 zł), Rewal (13 828 zł), Stepnica (8767 zł), Ostrowice (7770 zł), Ustronie Morskie (7601 zł) i Mielno (7508 zł). W województwie pomorskim najwyższe wartości zanotowano w gminach: Sztutowo (8049 zł) i Gniewino (5239 zł). W latach 2003-2013 w przypadku niektórych gmin wzrost dochodów na 1 mieszkańca był znaczący, niekiedy kilkakrotny, jak to miało miejsce np. w gminie Stepnica (w 2003 r. - 1513 zł, w 2013 r. - 8767 zł; wzrost o 479,4\%) czy Sztutowo (w 2003 r. - 1691 zł, w 2013 r. - 8049 zł; wzrost o 375,8\%). Jednak największy wzrost dochodów w tym okresie, wynoszący 1391,1\%, zanotowano w gminie Nowe Warpno (w 2003 r. - 1983 zł na 1 mieszkańca, w 2013 r. - 29576 zł). 

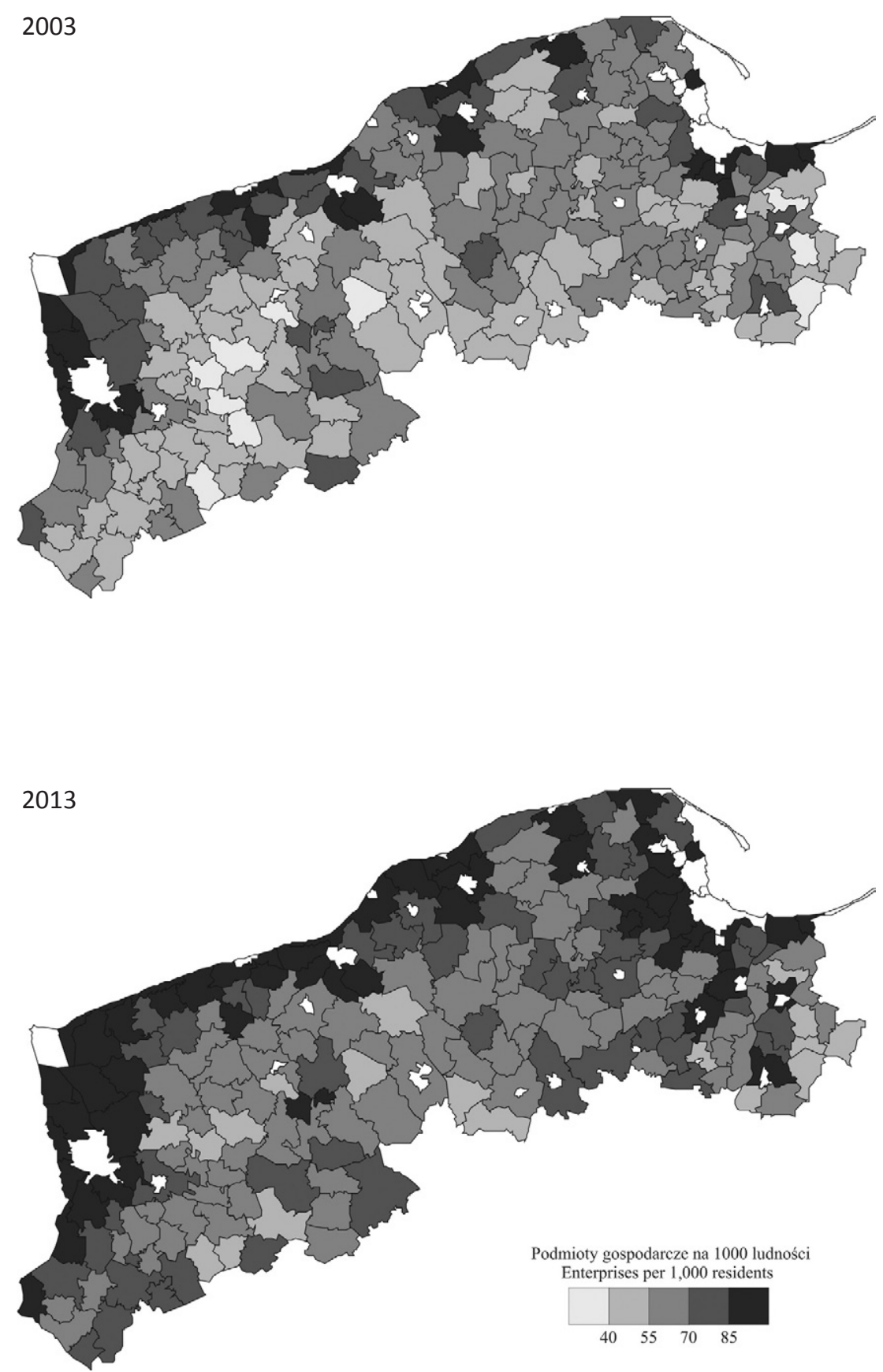

Ryc. 2. Podmioty gospodarcze w gminach Pomorza w 2003 i 2013 r.

Źródło: opracowanie własne na podstawie danych GUS, Bank Danych Lokalnych;www.stat.gov.pl (dostęp z dnia 18.05.2015)

Enterprises in the communes of Pomerania in 2003 and 2013 per 1,000 inhabitants

Source: own study based on data from the CSO Local Data Bank; www.stat.gov.pl (access: 18.05.2015) 


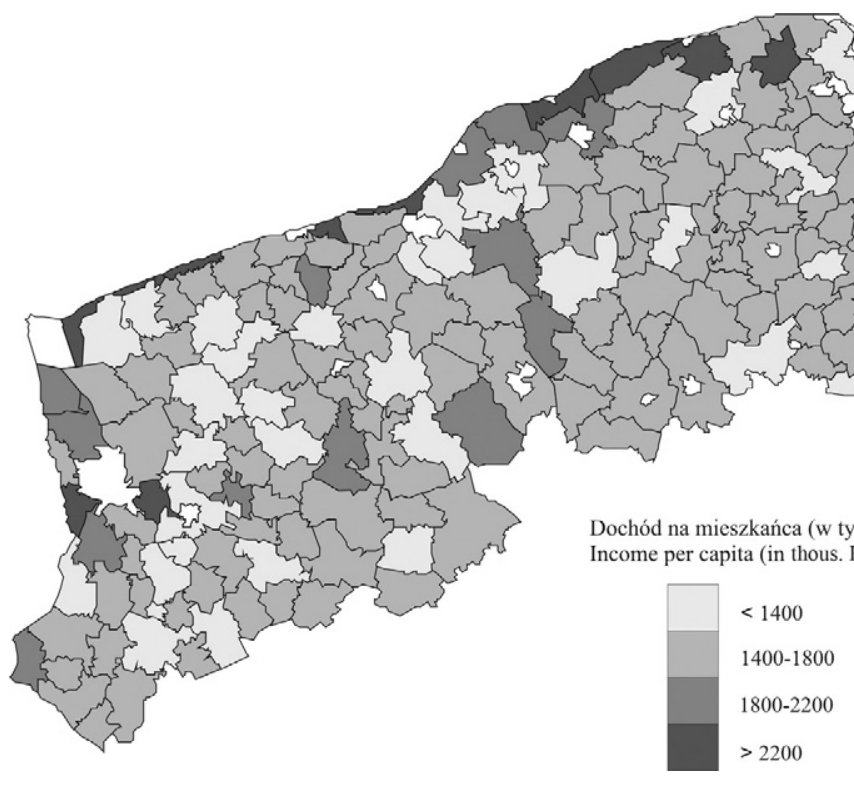

Ryc. 3. Dochód na 1 mieszkańca na obszarach wiejskich w gminach Pomorza w 2003 r.

Źródło: opracowanie własne na podstawie danych GUS, Bank Danych Lokalnych; www.stat.gov.pl (dostęp z dnia 8.05.2015)

Income per capita in rural areas in the communes of Pomerania in 2003

Source: own study based on data from the CSO Local Data Bank; www.stat.gov.pl (access: 8.05.2015)

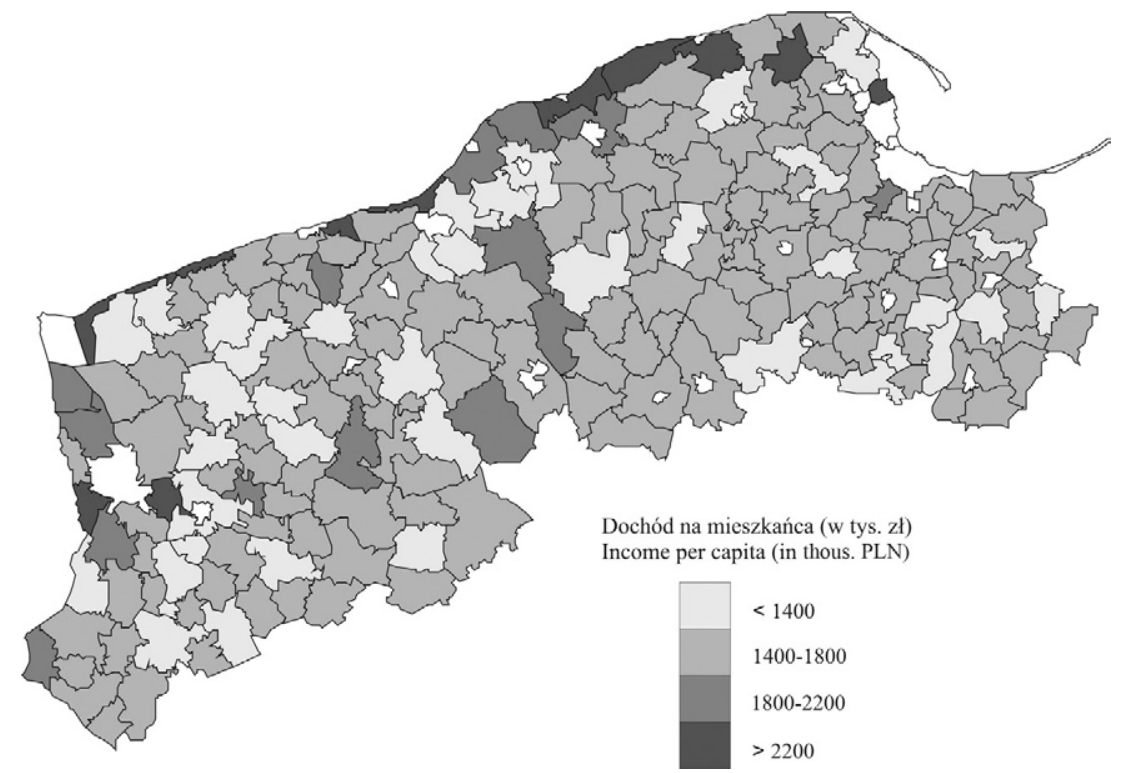

Ryc. 4. Dochód na 1 mieszkańca na obszarach wiejskich w gminach Pomorza w 2013 r.

Źródło: opracowanie własne na podstawie danych GUS, Bank Danych Lokalnych; www.stat.gov.pl(dostęp z dnia 18.05.2015)

Income per capita in rural areas in the communes of Pomerania in 2013

Source: own study based on data from the CSO Local Data Bank; www.stat.gov.pl (access: 18.05.2015) 


\section{Zmiany w pomorskim rolnictwie po akcesji do Unii Europejskiej}

Przystąpienie Polski do UE oznaczało dla polskiego rolnictwa istotne zmiany warunków produkcji, a zarazem rewolucję instytucjonalną: zmienił się sposób wspierania tego sektora, zaczęły obowiązywać inne zasady interwencji i skupu, pojawiły się nowe instrumenty wspierające modernizację gospodarstw, zniesiono bariery w handlu zagranicznym produktami rolno-spożywczymi z krajami UE. Projekt cywilizacyjny dla polskiej wsi, jakim jest Wspólna Polityka Rolna, wywarł znaczący wpływ nie tylko na ekonomiczne warunki produkcji, ale również na społeczność wiejską. Rolnicy musieli szybko dostosować się do nowej sytuacji i podjąć istotne decyzje co do przyszłości swoich gospodarstw. Akcesja Polski do UE oznaczała skierowanie znaczących funduszy nie tylko do samego rolnictwa, ale też na obszary wiejskie, m.in. poprzez fundusze strukturalne. Zatem polityka rozwoju wsi nie była realizowana, jak dotychczas, jedynie poprzez wspieranie rolnictwa, ale poprzez wiele działań z zakresu polityki edukacyjnej, przedsiębiorczości, infrastrukturalnej czy ochrony środowiska (Poczta i Herdt 2005).

Według danych GUS, do końca 2013 r. w ramach PROW 2007-2013 na pomorską wieś trafiło łącznie blisko $5 \mathrm{mld}$ zł (w województwie pomorskim ponad 2,367 mld zł, zachodniopomorskim - 2,562 mld zł). Najwięcej środków finansowych na badanym terenie wydatkowano na realizację działań wdrażanych w zakresie pierwszych dwóch osi priorytetowych: Osi 1 i Osi 2, które odpowiednio stanowiły 1,545 mld zł (31,3\% środków finansowych) i 2,538 mld zł (51,5\%). Działania te finansowane były z Europejskiego Funduszu Rolnego na Rzecz Rozwoju Obszarów Wiejskich oraz współfinansowane z krajowego budżetu. Wartość środków Unii Europejskiej w przeliczeniu na 1 mieszkańca wsi Pomorza wynosiła średnio 3680 zł, przy czym zdecydowanie wyższa była w województwie zachodniopomorskim - 4751 zł (w pomorskim - 2958 zł). Z kolei przeliczając wartość dofinansowania na 1 ha powierzchni obszarów wiejskich, dysproporcje w tym zakresie są zdecydowanie mniejsze. W przypadku województwa pomorskiego kwota, nieznacznie wyższa, wynosiła 1377 zł, zaś zachodniopomorskiego - 1193 zł; średnia dla Pomorza wynosiła 1274 zł.

Wejście Polski do Unii Europejskiej w 2004 r. stworzyło możliwość przeprowadzenia restrukturyzacji i modernizacji rolnictwa oraz dało początek pozytywnym zmianom na obszarach wiejskich. Pozyskane przez rolników środki finansowe przyczyniły się do zmniejszenia różnic przestrzennych, co było przede wszystkim priorytetem w ramach WPR dla obszarów o niższym poziomie rolnictwa, z reguły charakteryzujących się niekorzystnymi warunkami gospodarowania (Rudnicki 2010).

Rolnicza przestrzeń produkcyjna Pomorza jest bardzo zróżnicowana pod względem jakości przyrodniczo-glebowej, warunkującej jej przydatność dla produkcji rolnej, struktury agrarnej i sposobu organizacji gospodarstw, poziomu inwestowania i stosowanych technologii w produkcji. Najwyższy potencjał agroekologiczny (wskaźnik waloryzacji rolniczej przestrzeni produkcyjnej ${ }^{1}$ - wwrpp powyżej 80 pkt) na terenie województwa pomorskiego posiadają: Żuławy Wiślane i Dolina Dolnej Wisły, zaś wysoki: obszary na północy (Równina Słupska, Wysoczyzna Damnicka, Wysoczyzna Żarnowiecka) oraz na południu (Pojezierze Krajeńskie). Z kolei w województwie zachodniopomorskim najbardziej korzystne warunki środowiska przyrodniczego występują w południowo-zachodniej części województwa (ryc. 5). Obszary o najwyższym wskaźniku charakteryzują się przede wszystkim zgrupo-

\footnotetext{
1 Wskaźnik odzwierciedla potencjał rolniczej przestrzeni produkcyjnej, wynikający z warunków naturalnych (jakość gleb, agroklimat, warunki wodne, rzeźba terenu).
} 
waniem gleb o najwyższej i wysokiej przydatności, wysokim udziałem użytków rolnych, a także rozwiniętą i utrwaloną przez lata funkcją rolną z przetwórstwem rolno-spożywczym. Z kolei najmniej korzystne warunki środowiska przyrodniczego na badanym obszarze (wwrpp poniżej 50 pkt) występują w tych częściach regionu, które wyróżniają się największą lesistością. Średnia wartość wskaźnika dla województwa pomorskiego wynosi 66,2 pkt, zaś dla województwa zachodniopomorskiego 67,5 pkt. Zatem znacząco nie odbiega od średniej krajowej (66,6 pkt).

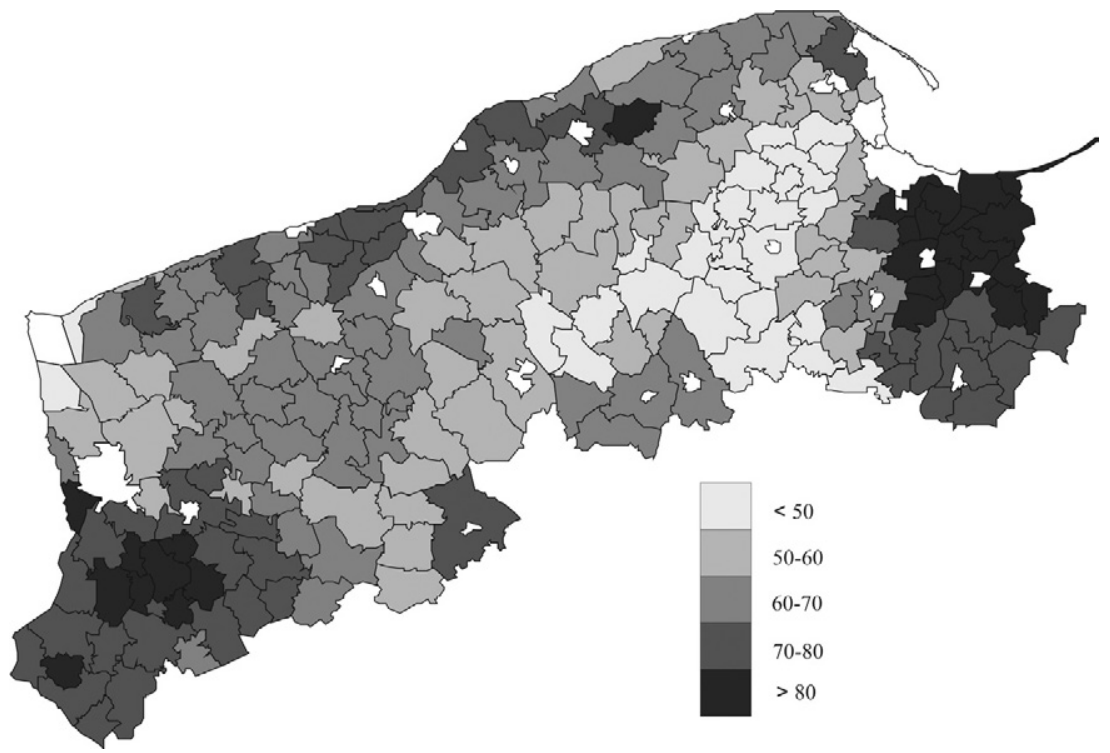

Ryc. 5. Waloryzacja rolniczej przestrzeni produkcyjnej Pomorza

Źródło: opracowanie własne na podstawie danych IUNG w Puławach.

Evaluation of agricultural production in Pomerania

Source: own study based on IUNG data

Przed okresem transformacji gospodarczej podstawową funkcją wsi Pomorza było rolnictwo, ze względu na znaczne zasoby potencjału rolnego oraz wysoki udział gruntów sektora publicznego. Jednak, pomimo iż w ostatnich latach coraz większego znaczenia nabiera rozwój pozarolniczych form działalności gospodarczej, to nadal istotną rolę w rozwoju na wielu obszarach współczesnej pomorskiej wsi nadal odgrywa rolnictwo. Z danych GUS wynika, iż na koniec 2013 r. użytki rolne stanowiły w województwie pomorskim 40,3\% powierzchni ogólnej, zaś w województwie zachodniopomorskim - 37,5\% (tab. 2). Na Pomorzu w latach 2004-2013 ich udział zmalał - w przypadku województwa pomorskiego o 3,7 punkta procentowego, natomiast w województwie zachodniopomorskim tendencja spadkowa jest bardziej widoczna i wyniosła 9,7 punkta procentowego. 
Tabela 2. Powierzchnia użytków rolnych i lasów na Pomorzu w latach 2004-2013

\begin{tabular}{|c|c|c|c|c|c|c|c|c|c|c|c|c|c|c|c|c|c|c|c|c|}
\hline \multirow{3}{*}{ Wyszczególnienie } & \multicolumn{20}{|c|}{ Lata } \\
\hline & \multicolumn{2}{|c|}{2004} & \multicolumn{2}{|c|}{2005} & \multicolumn{2}{|c|}{2006} & \multicolumn{2}{|c|}{2007} & \multicolumn{2}{|c|}{2008} & \multicolumn{2}{|c|}{2009} & \multicolumn{2}{|c|}{$2010^{*}$} & \multicolumn{2}{|c|}{2011} & \multicolumn{2}{|c|}{2012} & \multicolumn{2}{|c|}{2013} \\
\hline & tys. ha & $\%$ & tys. ha & $\%$ & tys. ha & $\%$ & tys. ha & $\%$ & tys. ha & $\%$ & tys. ha & $\%$ & tys. ha & $\%$ & tys. ha & $\%$ & tys. ha & $\%$ & tys. ha & $\%$ \\
\hline \multicolumn{21}{|c|}{ Województwo pomorskie } \\
\hline $\begin{array}{l}\text { Powierzchnia } \\
\text { użytków rolnych }\end{array}$ & 803,6 & 43,9 & 773,6 & 42,2 & 785,2 & 42,9 & 770,0 & 42,0 & 762,3 & 41,6 & 772,3 & 42,2 & 750,1 & 40,9 & 739,3 & 40,4 & 747,3 & 40,8 & 738,2 & 40,3 \\
\hline $\begin{array}{l}\text { Powierzchnia } \\
\text { lasów }\end{array}$ & 672,5 & 35,8 & 674,3 & 35,9 & 674,9 & 36,0 & 676,6 & 36,0 & 677,6 & 36,1 & 679,1 & 36,2 & 680,4 & 36,2 & 681,1 & 36,2 & 682,1 & 36,3 & 682,9 & 36,3 \\
\hline \multicolumn{21}{|c|}{ Województwo zachodniopomorskie } \\
\hline $\begin{array}{l}\text { Powierzchnia } \\
\text { użytków rolnych }\end{array}$ & 1081,7 & 47,2 & 1032,5 & 45,1 & 984,8 & 43,9 & 975,3 & 42,0 & 965,4 & 43,5 & 953,3 & 42,6 & 909,8 & 40,6 & 866,8 & 38,7 & 868,5 & 38,8 & 838,7 & 37,5 \\
\hline $\begin{array}{l}\text { Powierzchnia } \\
\text { lasów }\end{array}$ & 818,1 & 34,7 & 820,4 & 34,8 & 822,6 & 34,9 & 823,8 & 34,9 & 825,2 & 35,0 & 826,9 & 35,1 & 828,6 & 35,2 & 832,3 & 35,3 & 833,3 & 35,4 & 833,9 & 35,4 \\
\hline
\end{tabular}

* od 2010, powierzchnia użytków rolnych zgodnie z nową definicją

Źródło: opracowanie własne na podstawie danych GUS, Bank Danych Lokalnych; www.stat.gov.pl (dostęp: 23.05.2015) 
Do obszarów typowo rolniczych o największym odsetku użytków rolnych zaliczyć należy południowo-zachodnią część regionu (powiat gryficki i łobeski), północno-środkową (powiat koszaliński, białogardzki, słupski) oraz południowo-wschodnią (powiat malborski, sztumski, kwidzyński). Na szczególną uwagę zasługuje powiat malborski, gdzie aż 4 spośród 5 gmin cechuje wysoka wartość wskaźnika, wynosząca ponad 80\% (Miłoradz, Malbork, Nowy Staw, Lichnowy). Warto dodać, iż tak znaczący odsetek użytków rolnych w ogólnej powierzchni występuje także w gminach Będzino (80\%), Karlino (78\%) czy Dobra (77\%). Udział użytków rolnych w ogólnej powierzchni jest czynnikiem przesądzającym o rolniczym charakterze tych obszarów, a jednocześnie narzuca kierunek aktywności ekonomicznej ich mieszkańców. Warto podkreślić, że na badanym terenie, wraz ze spadkiem udziału użytków rolnych wzrastał udział lasów, które są jednym z ważniejszych zasobów regionu i zajmują 1/3 ogólnej powierzchni Pomorza. W województwie pomorskim na koniec 2013 r. stanowiły 36,3\% powierzchni, a w zachodniopomorskim - 35,4\%. Ich udział w niewielkim stopniu, ale systematycznie wzrasta. W okresie 2004-2013 odnotowano wzrost o 0,7 punkta procentowego w województwie zachodniopomorskim i 0,5 punkta procentowego w pomorskim. Najwyższy wskaźnik lesistości w regionie, wynoszący ponad 70\%, cechuje gminy powiatu starogardzkiego - Osieczna (76\%), Kaliska (71,1\%) oraz Osiek (71,1\%) w województwie pomorskim, a także gminę Człopa $(71,8 \%)$ w województwie zachodniopomorskim.

Rozwój obszarów wiejskich i rolnictwa, wspomagany przez finansowe mechanizmy Wspólnej Polityki Rolnej, spowodował z jednej strony wyraźny wzrost znaczenia pozarolniczych form działalności, a z drugiej wywołał pozytywne zmiany w strukturze obszarowej rolnictwa. W latach 2003-2013 liczba gospodarstw zmniejszyła się o 48,6\%, przy czym w województwie zachodniopomorskim spadek był zdecydowanie większy $(57,5 \%)$, aniżeli w województwie pomorskim (45,8\%). Biorąc pod uwagę grupy obszarowe gospodarstw rolnych w 2013 r., ponad 1/3 stanowiły gospodarstwa małe o powierzchni nieprzekraczającej 5 ha (tab. 3). W województwie zachodniopomorskim ich udział stanowił 39,4\%, zaś w pomorskim - 36,1\%. Prowadzą one z reguły ekstensywną produkcję.

Tabela 3. Gospodarstwa rolne na Pomorzu według grup obszarowych w roku 2003 i 2013

\begin{tabular}{|l|c|c|c|c|c|c|c|c|}
\hline \multirow{2}{*}{$\begin{array}{c}\text { Grupy } \\
\text { obszarowe } \\
\text { (w ha) }\end{array}$} & \multicolumn{3}{|c|}{ Województwo pomorskie } & \multicolumn{3}{c|}{ Województwo zachodniopomorskie } \\
\cline { 2 - 9 } & \multicolumn{2}{|c|}{$\mathbf{2 0 0 3}$} & \multicolumn{2}{|c|}{$\mathbf{2 0 1 3}$} & \multicolumn{2}{c|}{$\mathbf{2 0 0 3}$} & \multicolumn{2}{c|}{$\mathbf{2 0 1 3}$} \\
\cline { 2 - 9 } & liczba & \% & liczba & \% & liczba & \% & liczba & $\%$ \\
\hline$<1$ & 22124 & 30,0 & 727 & 1,8 & 25927 & 37,9 & 418 & 1,4 \\
$1-2$ & 11076 & 15,0 & 5037 & 12,6 & 10478 & 15,3 & 4279 & 14,7 \\
$2-5$ & 11266 & 15,3 & 8661 & 21,7 & 8298 & 12,1 & 6767 & 23,3 \\
$5-10$ & 10348 & 14,0 & 8478 & 21,2 & 6825 & 10,0 & 5004 & 17,2 \\
$10-15$ & 7622 & 10,3 & 6019 & 15,0 & 4652 & 6,8 & 3215 & 11,0 \\
$15-20$ & 3968 & 5,4 & 3265 & 8,2 & 4292 & 6,3 & 1963 & 6,8 \\
$20-30$ & 2857 & 3,9 & 3155 & 7,9 & 2607 & 3,8 & 2195 & 7,6 \\
$30-50$ & 2815 & 3,8 & 2367 & 5,9 & 2926 & 4,3 & 1840 & 6,3 \\
$50-100$ & 981 & 1,3 & 1383 & 3,5 & 1361 & 2,0 & 1814 & 6,2 \\
$>100$ & 662 & 0,9 & 864 & 2,2 & 1002 & 1,5 & 1566 & 5,4 \\
\hline Ogółem & 73719 & 100,0 & 39956 & 100,0 & 68368 & 100,0 & 29062 & 100,0 \\
\hline
\end{tabular}

Źródło: opracowanie własne na podstawie danych MRiRW; www.minrol.gov.pl i danych GUS, Bank Danych Lokalnych; www. stat.gov.pl (dostęp: 13.05.2015) 
Preferowany staje się model gospodarstwa wielofunkcyjnego i przyjaznego środowisku. Trend ten jest szczególnie istotny dla małych gospodarstw, gdzie może być prowadzona produkcja dobrej jakościowo żywności z wykorzystaniem tradycyjnych regionalnych receptur. Dzięki temu mogą zostać zachowane walory krajobrazowe i kulturowe oraz powstawać atrakcyjne miejsca rekreacji i wypoczynku (Czapiewska 2014). W badanym okresie (2003-2013) udział gospodarstw w tej grupie wielkościowej zmalał na korzyść gospodarstw większych obszarowo. Fakt ten z punktu widzenia poprawy struktury agrarnej należy uznać za pozytywny. W sposób znaczący wzrósł udział gospodarstw wielkoobszarowych (100 ha i więcej) - w województwie zachodniopomorskim o 53,3\% i pomorskim o 30,5\%. Nie sposób również nie wspomnieć, że na badanym terenie są jeszcze takie wsie, gdzie formalnie działalność rolniczą prowadzi kilkadziesiąt gospodarstw, a prawdziwych rolników jest zaledwie kilku. Pozostali swoją ziemię nieoficjalnie wydzierżawili bądź tylko pobierają dopłaty unijne. Z obserwacji wynika, iż w niektórych wsiach jest to zjawisko dość powszechne.

W badanym okresie na Pomorzu wzrosła także średnia powierzchnia gruntów rolnych w gospodarstwie (tab. 4). Obecnie przeciętna powierzchnia gospodarstwa rolnego o powierzchni powyżej 1 ha jest w regionie pomorskim wyższa, aniżeli średnia w skali kraju (10,42 ha). W 2013 r. wynosiła odpowiednio 30,3 ha w województwie zachodniopomorskim i 18,95 ha w województwie pomorskim.

Tabela 4. Średnia wielkość powierzchni gruntów rolnych w gospodarstwie rolnym na Pomorzu w latach 2006-2013

\begin{tabular}{|c|c|c|c|c|c|c|c|c|}
\hline \multirow{2}{*}{ Wyszczególnienie } & 2006 & 2007 & 2008 & 2009 & 2010 & 2011 & 2012 & 2013 \\
\hline & \multicolumn{8}{|c|}{ Powierzchnia gruntów (w ha) } \\
\hline $\begin{array}{l}\text { Województwo } \\
\text { pomorskie }\end{array}$ & 17,99 & 18,30 & 18,48 & 18,82 & 18,84 & 19,00 & 18,94 & 18,95 \\
\hline $\begin{array}{l}\text { Województwo } \\
\text { zachodniopomorskie }\end{array}$ & 28,37 & 29,18 & 29,68 & 30,15 & 30,30 & 30,70 & 30,67 & 30,30 \\
\hline Polska & 9,52 & 9,91 & 10,02 & 10,15 & 10,23 & 10,36 & 10,38 & 10,42 \\
\hline
\end{tabular}

Źródło: opracowanie na podstawie danych ARiMR, www.arimr.gov.pl (dostęp: 17.05.2015)

Jedną z najszybciej rozwijających się obecnie gałęzi rolnictwa na świecie, w tym w szczególności w Unii Europejskiej, jest rolnictwo ekologiczne. Jego znaczenie rośnie wraz ze wzrostem świadomości ekologicznej nie tylko konsumentów, ale również rolników. Rozwój sektora rolnictwa ekologicznego cechuje stała dynamika wzrostu powierzchni użytkowanej i liczby gospodarstw ekologicznych, jak również wzrost liczby przetwórni czy dostępnego na rynku asortymentu produktów ekologicznych.

Na Pomorzu również systematycznie wzrasta liczba gospodarstw ekologicznych z certyfikatem, jak i w okresie przestawiania (tab. 5). W latach 2006-2013 na terenie województwa pomorskiego liczba gospodarstw z certyfikatem wzrosła 9-krotnie, natomiast w województwie zachodniopomorskim aż 16-krotnie. Warto dodać, że województwo zachodniopomorskie pod względem liczby gospodarstw ekologicznych, która wynosiła 3640 na koniec 2013 r. (13,7\% ogólnej ich liczby w kraju), znajdowało się na drugim miejscu, po województwie warmińsko-mazurskim (4235 gospodarstw) i na pierwszym miejscu pod względem powierzchni użytkowanej ekologicznie (143 648,2 ha). Obecnie większość z nich ukierunkowana jest na produkcję roślinną, głównie zbożową. 
Zasadniczym czynnikiem motywującym rolników do zmiany konwencjonalnego systemu prowadzenia gospodarstwa na ekologiczny są niewątpliwie dopłaty rolnośrodowiskowe w ramach PROW. Przysługują one rolnikom, którzy stawiają na wdrażanie przyjaznych środowisku praktyk rolniczych, pozwalających m.in. na ograniczenia strat biogenów poprzez tworzenie tzw. stref buforowych, nasadzanie drzew wzdłuż dróg, cieków wodnych i rowów melioracyjnych, stosowanie wsiewek i międzyplonów.

Tabela 5. Rozwój rolnictwa ekologicznego na Pomorzu w latach 2006-2013

\begin{tabular}{|c|c|c|c|c|c|c|c|c|}
\hline \multirow{2}{*}{$\begin{array}{l}\text { Liczba gospodarstw } \\
\text { ekologicznych }\end{array}$} & \multicolumn{8}{|c|}{ Lata } \\
\hline & 2006 & 2007 & 2008 & 2009 & 2010 & 2011 & 2012 & 2013 \\
\hline \multicolumn{9}{|c|}{ Województwo pomorskie } \\
\hline Ogółem & 222 & 273 & 392 & 494 & 648 & 763 & 894 & 893 \\
\hline w tym: z certyfikatem & 69 & 166 & 223 & 245 & 348 & 460 & 601 & 645 \\
\hline $\begin{array}{l}\text { w okresie } \\
\text { przestawiania }\end{array}$ & 153 & 107 & 169 & 249 & 300 & 303 & 293 & 248 \\
\hline \multicolumn{9}{|c|}{ Województwo zachodniopomorskie } \\
\hline Ogółem & 678 & 1059 & 1396 & 1696 & 2373 & 3065 & 3579 & 3640 \\
\hline w tym: z certyfikatem & 163 & 375 & 571 & 895 & 1312 & 1607 & 2194 & 2669 \\
\hline $\begin{array}{l}\text { w okresie } \\
\text { przestawiania }\end{array}$ & 515 & 684 & 825 & 801 & 1061 & 1458 & 1385 & 971 \\
\hline
\end{tabular}

Źródło: opracowanie własne na podstawie danych MRiRW; www.minrol.gov.pl i danych GUS, Bank Danych Lokalnych; www. stat.gov.pl (dostęp: 13.05.2015)

Z danych Raportu Głównego Inspektoratu Jakości Handlowej Artykułów Rolno-Spożywczych (IJHARS) wynika, iż na koniec 2012 r. funkcjonowało na badanym terenie 41 przetwórni ekologicznych, w tym 24 w województwie zachodniopomorskim i 17 w pomorskim (Raport o stanie... 2013).

W regionie pomorskim rośnie także liczba grup producentów rolnych (tab. 6). Powstają one głównie w regionach, gdzie dominują gospodarstwa towarowe i specjalistyczne, a wśród nich są też takie, które niegdyś należały do sektora gospodarki uspołecznionej (Czapiewska 2013). Funkcjonujące w regionie pomorskim grupy producenckie specjalizują się przede wszystkim w produkcji zbóż i nasion roślin oleistych. Według danych Urzędu Marszałkowskiego na koniec 2013 r. na obszarze województwa pomorskiego w rejestrze przedsiębiorców figurowało 77 grup producentów rolnych, a zachodniopomorskiego 66. Największą ich liczbę zarejestrowano w 2013 r. (50), co stanowiło 35\% utworzonych łącznie grup producenckich na Pomorzu w latach 2004-2013. 
Tabela 6. Rozwój grup producentów rolnych na Pomorzu w latach 2004-2013

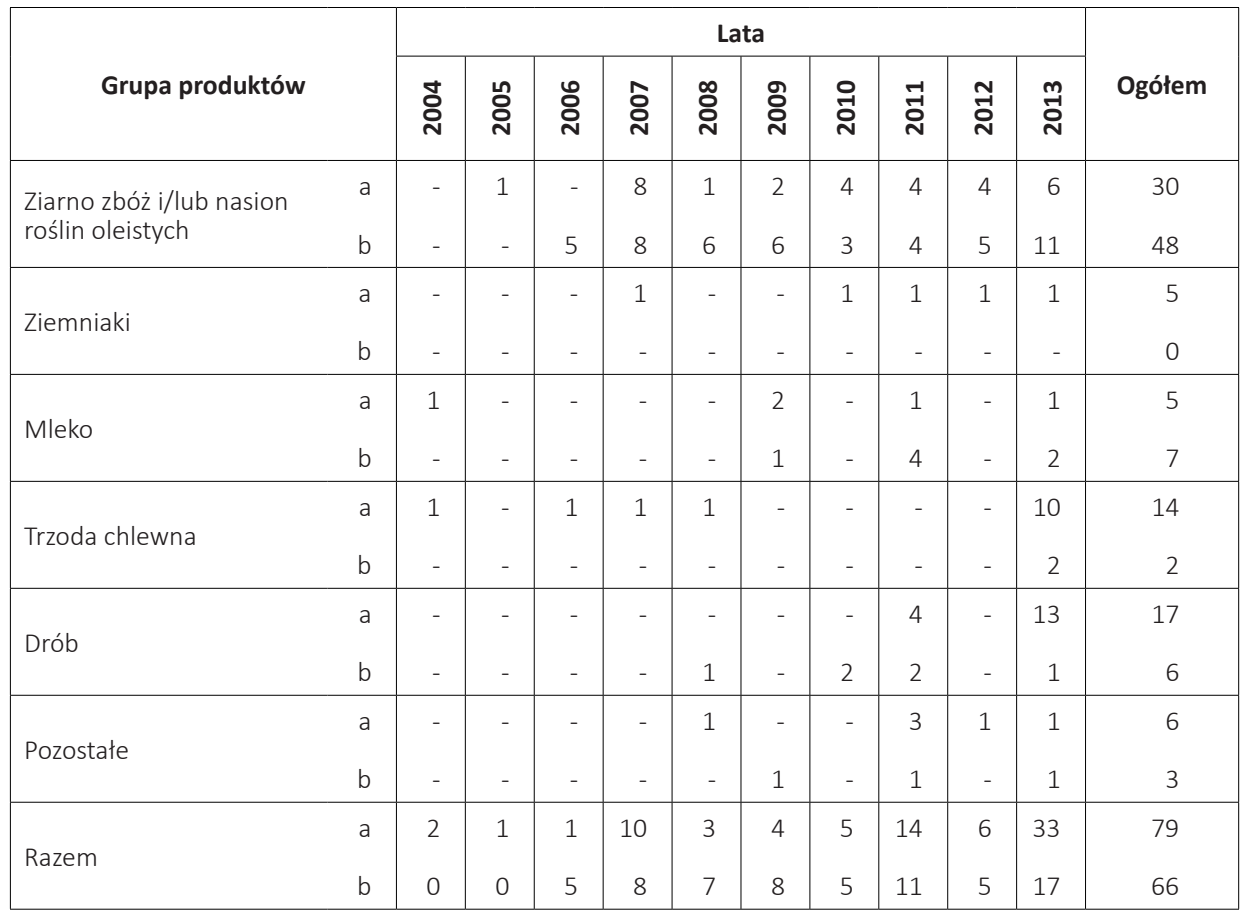

a - województwo pomorskie, b - województwo zachodniopomorskie

Źródło: Opracowanie własne na podstawie rejestru grup producentów rolnych MRiRW ; www.minrol.gov.pl (dostęp: 11.05.2015)

Na Pomorzu istnieją znaczne możliwości rozwoju odnawialnych źródeł energii. Za jeden z najbardziej przyszłościowych kierunków energetycznego wykorzystania zasobów biomasy uznaje się produkcję biogazu rolniczego. Biogazownie tego typu, z uwagi na rodzaj pozyskiwanych substratów oraz specyfikę ich działania, idealnie wpisują się w wiejski krajobraz. Z rejestru Agencji Rynku Rolnego wynika, iż na koniec 2013 r. funkcjonowało w kraju 37 biogazowni rolniczych. Wśród operatorów niekwestionowanym liderem w skali kraju jest firma Poldanor S.A - nowoczesne wielkotowarowe przedsiębiorstwo rolne z udziałem kapitału duńskiego. Eksploatuje łącznie 8 biogazowni rolniczych, zlokalizowanych w: Koczale, Pawłówku, Płaszczycy, Uniechówku, Kujankach (woj. pomorskie), Nacławiu, Świelinie, Giżynie (woj. zachodniopomorskie).

Reforma Wspólnej Polityki Rolnej, przeprowadzona w czerwcu 2003 r., poszerzyła politykę rozwoju obszarów wiejskich, nadając im jednocześnie większe znaczenie. Realizacja programu WPR, wyrażająca się m.in. wprowadzeniem dopłat bezpośrednich, wspieraniem produkcji gospodarstw niskotowarowych, dostosowaniem gospodarstw do standardów unijnych, regulacją rynku rolnego itd., wpłynęła zarówno na zmiany kierunków produkcji rolniczej, jak i szeroko rozumiane funkcjonowanie obszarów wiejskich (Golik 2006; Marcysiak 2009). 


\section{Podsumowanie}

W ciągu ostatnich lat zmianie uległa polityka skierowana na obszary wiejskie. W znacznej mierze położono nacisk na zrównoważony rozwój, wielofunkcyjność, a szczególnie na wzrost konkurencyjności, poprawę stanu środowiska naturalnego oraz poprawę warunków życia ludności wiejskiej. Obecnie jednym z głównych czynników rozwoju lokalnego i regionalnego są niewątpliwie środki finansowe pochodzące z budżetu Unii Europejskiej. Od 2004 r. na obszarach wiejskich Pomorza zauważalne jest znaczące ożywienie, zarówno gospodarcze, jak i społeczne. Możliwość pozyskania dofinansowania na prowadzenie własnej firmy motywuje ludność wiejską do prowadzenia działalności o charakterze pozarolniczym. Warto jednak podkreślić, iż uwarunkowania przyrodniczo-produkcyjne na badanym terenie na ogół sprzyjają rozwojowi rolnictwa, które jest integralną częścią pomorskiej gospodarki i pomorskiego społeczeństwa.

Wspólna Polityka Rolna oraz wdrażanie w latach 2004-2013 kolejnych programów unijnych: SAPARD, SPO Rolnictwo 2004-2006, Plan Rozwoju Obszarów Wiejskich 2004-2006 i Programu Rozwoju Obszarów Wiejskich 2007-2013 zdecydowanie odmieniły obraz pomorskiego rolnictwa, które obecnie charakteryzuje się coraz większą liczbą wielkopowierzchniowych indywidualnych gospodarstw rolnych, wyposażonych w nowoczesny park maszynowy. W sposób wyraźny uwidacznia się rozwój ekonomiki prowadzonej działalności, która jest przyjazna środowisku i uwzględnia najnowsze trendy (rolnictwo zrównoważone). Dzięki środkom unijnym coraz większy udział w produkcji rolnej zyskują zorganizowane formy zespołowego gospodarowania - grupy producentów rolnych. Potrzeba organizowania się rolników to w dzisiejszych realiach już konieczność, która umożliwia dostosowanie do potrzeb rynku, stymulowanego silną konkurencją ze strony rolnictwa europejskiego.

$\mathrm{Na}$ badanych obszarach wiejskich Pomorza, poza zmianami o charakterze stricte ekonomicznym, uwidoczniły się także istotne przeobrażenia w tkance społecznej wsi. Coraz bardziej widoczne są różnorodne przejawy aktywizacji i integracji społeczności wiejskich. Wymienić można chociażby Lokalne Grupy Działania (LGD), Lokalne Grupy Rybackie (LGR) czy wsie tematyczne. Obecnie na terenie Pomorza funkcjonuje 31 LGD (w województwie pomorskim 16 i zachodniopomorskim 15), 13 LGR (w pomorskim 8 i zachodniopomorskim 7) oraz 10 wsi tematycznych (w pomorskim 2 i zachodniopomorskim 8) (Czapiewska 2012a, b, c). Na badanym terenie systematycznie wzrasta także liczba organizacji pozarządowych (fundacji, stowarzyszeń i organizacji społecznych). Z danych GUS wynika, iż w 2013 r. na terenie Pomorza funkcjonowało ich łącznie 12789 (w województwie pomorskim 5558, zachodniopomorskim 7231), z czego 28,2\% na obszarach wiejskich (odpowiednio 1565 i 2046). Na przestrzeni lat 2003-2013 udział organizacji pozarządowych na obszarach wiejskich obu województw wzrósł o 48,1\% (z 1739 w 2003 r. do 3611 w 2013 r.).

Zróżnicowanie zasobów obszarów wiejskich ma potencjalnie szerokie możliwości kreowania innowacji, rozwoju i wykorzystania odnawialnych źródeł energii, zwłaszcza biogazowni rolniczych oraz rozwoju działalności pozarolniczej. Zatem współczesny rozwój społeczno-ekonomiczny obszarów wiejskich Pomorza w dużym stopniu uwarunkowany jest możliwością absorpcji środków finansowych Unii Europejskiej. 


\section{Literatura}

Bański J., 2013, Polska wieś w perspektywie 2050 roku, Studia Obszarów Wiejskich, 33, PTG, IGiPZ PAN, Warszawa.

Bański J., 2014, Perspektywy rozwoju polskiej wsi-wybrane zagadnienia, Wieś i Rolnictwo, 4 (165), s. 1-13.

Czapiewska G., 2012a, Lokalne grupy działania a kreowanie rozwoju regionalnego w województwach pomorskim i zachodniopomorskim, Nierówności społeczne a wzrost gospodarczy, 29, s. 401-413.

Czapiewska G., 2012b, Rola lokalnych grup rybackich w rozwoju obszarów wiejskich województw nadmorskich, Rozprawy naukowe Instytutu Geografii i Rozwoju Regionalnego Uniwersytetu Wrocławskiego, 29, s. 141-153.

Czapiewska G., 2012c, Wioski tematyczne sposobem na aktywizację gospodarczą i społeczna regionu, Studia i Materiały. Miscellanea Oeconomicae, 1, s. 109-123.

Czapiewska G., 2013, Grupy producentów rolnych w rozwoju obszarów wiejskich Pomorza. Acta Universitatis Lodziensis, Folia geographica socio-oeconomica, 13, s. 165-178.

Czapiewska G., 2014, Współczesne wyzwania i zagrożenia rozwoju obszarów wiejskich Pomorza, Nierówności społeczne a wzrost gospodarczy, 38, s. 401-413.

Golik D., 2006, Kierunki restrukturyzacji obszarów wiejskich w Polsce, Zeszyty Naukowe Akademii Ekonomicznej w Krakowie, 709, Kraków.

Heffner K. (red.), 2013, Rozwój obszarów wiejskich w Polsce a polityka spójności Unii Europejskiej: Stare problemy i nowe wyzwania (ze szczególnym uwzględnieniem województwa opolskiego), Studia KPZK PAN, t. CLIV, Warszawa.

Kamińska W., 2011, Pozarolnicza aktywność gospodarcza osób fizycznych na obszarach wiejskich w Polsce, [w:] W. Kamińska, K. Heffner (red.), Obszary wiejskie, wielofunkcyjność, migracje, nowe wizje rozwoju, Studia KPZK PAN, t. CXXXIII, Warszawa, s. 103-127.

Kiniorska I., 2009, Zmiany warunków życia ludności wiejskiej regionu Gór Świętokrzyskich, Problemy Zagospodarowania Ziem Górskich, 56, PAN, Kraków, s. 31-39.

Kłodziński M., 1996, Wielofunkcyjny rozwój terenów wiejskich w Polsce i w krajach Unii Europejskiej, SGGW, Warszawa.

Marcysiak A., 2009, Czynniki różnicujqce poziom wsparcia gospodarstw środkami UE, Roczniki Naukowe Stowarzyszenia Ekonomistów Rolnictwa i Agrobiznesu, 9, 2, s. 153-158.

Poczta W., Herdt Ł., 2005, Skutki integracji Polski z UE dla rolnictwa i obszarów wiejskich - próba oceny [w:] R. Hykawy (red.), Polska w Unii Europejskiej. Doświadczenia pierwszego roku członkostwa, Urząd Komitetu Integracji Europejskiej, Warszawa, s. 115-166.

Raport o stanie rolnictwa ekologicznego w Polsce w latach 2011-2012, 2013, IJHAR-S, Warszawa.

Rosner A., 2010, Przestrzenne zróżnicowanie polskiej wsi pod względem rozwoju społeczno-gospodarczego. Procesy wyrównywania się różnic czy ich pogłębiania, materiały konferencyjne, IRWiR PAN, Warszawa.

Rosner A. (red.) 2012, Rozwój wsi i rolnictwa w Polsce. Aspekty przestrzenne i regionalne, IRWiR PAN, Warszawa.

Rudnicki R., 2010, Zróżnicowanie przestrzenne wykorzystania funduszy Unii Europejskiej przez gospodarstwa rolne w Polsce, Bogucki Wydawnictwo Naukowe, Poznań. 


\section{Summary}

In this article, with the example of Pomerania (Pomorskie and Zachodniopomorskie Voivodships) the changes taking place in rural areas in the first decade after the accession to the European Union have been presented. The influence of EU measures for contemporary processes of socio-economic transformation in examined villages have been discussed. Despite the fact that in recent years the development of non-agricultural economic activities is becoming more important, agriculture still plays an important role in the development of the contemporary Pomeranian village. The main stimulator for the changes will be the organic farming development and production of renewable energy sources. The production of agricultural biogas is considered one of the most prospective directions of the energy use of biomass resources. In Pomerania the number of farms implementing ecological methods is systematically increasing as well as the number of agricultural producer groups. The direction of development of the surveyed rural areas will be to a large extent determined by the economic policy-Common Agricultural Policy of the European Union (2014-2020). An important role in rural development in Pomerania also plays the social capital, which varies greatly throughout the region. With the accession of Poland to the EU, there have emerged (as part of the operational programs related to rural areas and fisheries) new opportunities for the development of local communities through establishing and operating local action groups and local fishing groups providing possibilities for local businesses. 
http://rcin.org.pl 